\title{
Innovation and the export performance of firms in transition economies: the relevance of the business environment and the stage of transition
}

\author{
Fisnik Reçica* \\ Staffordshire University, \\ Stoke on Trent, UK \\ and \\ Riinvest College, \\ Prishtinë, Kosovo \\ Email: fisnik.recica@riinvest.net \\ *Corresponding author
}

\section{Iraj Hashi}

Centre for Research on Emerging Economies,

Staffordshire University,

Stoke on Trent, UK

Email: i.hashi@staffs.ac.uk

\section{Ian Jackson}

Staffordshire University,

Stoke on Trent, UK

Email: i.jackson@staffs.ac.uk

\section{Besnik A. Krasniqi}

Staffordshire University,

Stoke on Trent, UK

and

Faculty of Economics,

University of Prishtina,

Prishtinë, Kosovo

Email: b.krasniqi@staffs.ac.uk

\begin{abstract}
This paper investigates the impact of product and process innovation on firms' export performance in transition economies (TEs) which embarked on a systemic change from a planned to a market economy in the early 1990s. The research builds on the technology gap theory and the analysis of the self-selection of firms into the export market. Unlike other studies that have focused on the export behaviour of firms in developed economies where business environment is generally stable and favourable, the paper controls for the relevance of business environment and the stage of transition on export performance of firms. The paper uses the firm-level Business Environment and Performance Survey data undertaken by the European Bank for Reconstruction
\end{abstract}


and Development in 2002, 2005 and 2008 in 29 TEs. Findings show that the impact of innovation on export performance increases with the transition reforms. Macroeconomic instability acts as a moderating factor of export performance in countries at high transition stage, as it pushes firms to export more, as a risk shifting mechanism. The main implication of the study is that the impact of some explanatory factors on export performance differs through the stages of transition.

Keywords: export performance; innovation; transition stage; quality of institutions; business environment; transition economies.

Reference to this paper should be made as follows: Reçica, F., Hashi, I., Jackson, I. and Krasniqi, B.A. (xxxx) 'Innovation and the export performance of firms in transition economies: the relevance of the business environment and the stage of transition', Int. J. Entrepreneurship and Small Business, Vol. X, No. Y, pp.xxx-xxx.

Biographical notes: Fisnik Reçica is a Lecturer at the Riinvest College, Prishtina, Kosovo and Affiliate Fellow at the CERGE-EI, Prague. He completed his MSc and PhD in Economics at the Staffordshire University, Stoke on Trent, UK. His work and research are focused on enterprise development, innovation, entrepreneurship and international business.

Iraj Hashi is a Professor of Economics at the Staffordshire University, Stoke on Trent, UK. He completed his MA in Economics at the University of Maryland (USA) and PhD in Economics at the Keele University. He has been working on various aspects of the process of transition to a market economy in former socialist countries, including privatisation and corporate governance, financial system reforms, enterprise restructuring, industrial competitiveness, bankruptcy and reorganisation, and entrepreneurship and SME development. He has held teaching positions at the Keele University and Staffordshire University.

Ian Jackson is an Enterprise Reader at the Staffordshire University, Stoke on Trent, UK. He completed his MA in Economics at the University of Manchester (UK) and PhD in Economics at the University of York (UK). He has been working on a number of applied issues including the role of cooperation in industrial clusters, poverty reduction policies in Sub-Saharan Africa and the economics effects of the 'empty nest' syndrome. He is also a distance learning Tutor at the School of Oriental and African Studies (SOAS) at the University of London, UK.

Besnik A. Krasniqi a Fulbright Scholar and holds his $\mathrm{MA}$ and $\mathrm{PhD}$ in Economics from the Staffordshire University, UK. He is an Associate Professor of Small Business and Entrepreneurship at the University of Prishtina (Kosovo) and Adjunct Professor at the Maastricht School of Management (NL). He held teaching and research fellowships in entrepreneurship at the Indiana University (US), University of Michigan (US), and Tuck School of Business (US). His work in the area of institutions, entrepreneurship, SMEs, transition economies appeared in leading international journals such as Small Bus. Econ., Int. Entrep. Manag. J., IJEBR and Econ. Syst.

This paper is a revised and expanded version of a paper entitled 'Innovation and the export performance of firms in transition economies: the relevance of the business environment and the stage of transition' presented at Institute for Small Business and Entrepreneurship (ISBE) Conference, Manchester, 5-6 November 2014. 


\section{Introduction}

The economic literature suggests that a firm's innovation activities are a significant driver behind its export performance (Wakelin, 1998; Sterlacchini, 1999; Roper and Love, 2002; Ozçelik and Taymaz, 2004; Damijan et al., 2008; Anh et al., 2009; Dana et al., 2016). More than 30 years ago, Krugman (1979) had shown that product innovation, which increases the variety of the products and makes them more attractive to customers, also promotes international trade. More recently, Melitz (2003) and Caldera (2009) have highlighted the role of productivity as the vehicle for this process. They argued that a firm self-selects into the export market on the basis of cost reductions and productivity improvements, both of which may result from process or product innovations. Furthermore, higher degrees of product novelty may also increase the competitiveness of firms in international markets and thus positively affect their export performance. Of course, firms active on international markets, particularly in more developed economies, will also learn about new products and processes, develop new links and contacts and gain access to better distribution networks. This 'learning by exporting' is expected to enhance innovation, in firms in laggard transition economies (TEs) (Salomon and Shaver, 2005) and more matured market economies (Lööf et al., 2015).

However, the economic milieu has been altogether different in TEs which have gone through major social, political and economic upheavals since 1990, and where the institutions of a market economy had to be built from basic fundamentals. The transformation from a centrally planned to a market economy have been recognised as an essential factor in the growing export performance of firms in these countries (Rodrik et al., 2004; Kaminski et al., 1996). However, the process of building a market economy is closely bound to the nature of the business environment and the nature and quality of institutions developed in the course of transition. Despite its vital importance, the impact of business environment on a firm's export performance in TEs has not been accounted for in previous studies because most have tended to investigate the export behaviour of firms in developed economies where business environment is generally stable and favourable.

In terms of the stage of transition, while there are some studies investigating the export performance of firms in TEs during the 1990s and 2000s, there are no studies focusing on the impact of the stage of transition on exports. It is accepted that the competitive profile of firms in Central Eastern European Countries (CEECs) has changed in the course of the consolidation of the new market economy (Havlik, 2000; Havlik et al., 2001; Hashi and Krasniqi, 2011). Over time, as the market system became more established and the institutions of a market economy strengthened, these firms changed their innovative activities towards improving the quality and marketing of their products.

The overarching aim of this research is to contribute to the literature on innovation and export performance in several areas. First, the paper investigates the impact of degrees of novelty of product innovation on export performance. Second, it considers a large number of business environment factors and, after grouping them into four distinct areas of macroeconomic stability (inflation and exchange rate), infrastructure, access to finance, and the rule of law, investigate their impact on export performance. Finally, this study accounts for the impact of the stages of transition reforms. None of these areas have been previously investigated for TEs. 
For this purpose, the data used in this investigation draws on the Business Environment and Performance Survey (BEEPS) database. This unique survey of a large number of firms in TEs has been undertaken by the European Bank for Reconstruction and Development in three rounds in 2002, 2005 and 2008.

The remainder of the paper is composed as follows. The next section reviews the literature on the theoretical basis of the relationship between innovation activity and export performance, business environment and stages of transitional reforms and the previous research on the determinants of export performance. Section 3 discusses research methodology. Section 4 presents the empirical findings. Finally, Section 5 concludes and offers some policy recommendations as well as highlights some limitations.

\section{Literature review}

\subsection{Theoretical basis}

The literature on the relationship between innovation and export performance is generally based on the technology gap theory developed by Krugman (1979). The model highlights the importance of innovation as a crucial determinant of international trade and suggests that patterns of trade are determined by a continuing process of innovation and technology transfer. Through product innovation firms increase the variety of the products which are more attractive to customers. This in turn affects the firm's export performance due to increased competitiveness (Sterlacchini, 2001; Ozçelik and Tamyaz, 2004; Damijan et al., 2008)

Following the logic the of Krugman (1979) model it can be asserted that exporting firms have a greater tendency to be more innovative than non-exporting firms and their degree of innovation novelty is expected to be higher. Innovation may take the form of completely new products (new to the market or even to the world) or upgrading of existing products. Higher degrees of product novelty may increase competitiveness of firms in international markets and thus positively affect their export performance, which is an issue largely neglected in the economic literature.

Alternatively, Melitz (2003) posits that firms have heterogeneous productivity levels and self-select themselves into the export market based on cost reduction and higher productivity level. Caldera (2009) suggests that it is the innovative firms that have the ability to charge a lower price due to a lower marginal cost of production. As Caldera argues, this cost reduction is the result of process innovation. This implies that firms which introduce process innovation in particular are more productive, have lower cost of production and consequently are more competitive in the foreign markets. It might be suggested that firms increase productivity through process innovation but remain competitive and increase their market share by introducing new or significantly improved products.

Furthermore, the relationship between innovation and export performance may not be unidirectional. Theoretical models on endogenous innovation and growth (Romer, 1990; Grossman and Helpman, 1994) suggest that trade contributes to the expansion of domestic growth and product varieties, indicating that the increase of exports driven by innovation will in turn increase domestic investments in innovation activities. Also, exporting firms may access diverse knowledge and information not available in the 
domestic market which can foster increased innovation (Salomon and Shaver, 2005). 'Learning by exporting' is expected to enhance innovation, especially when firms in laggard TEs such as those in the Western Balkan countries export to more developed countries. Of course, any learning by exporting effect might be reflected in increased innovation activities with a time lag as the newly absorbed knowledge requires some time to be transformed into new products or processes.

\subsection{The impact of business environment and export performance}

In addition to theories linking export performance to productivity or innovation, the literature (Johanson and Vahlne, 1977; Cooper and Kleinschmidt, 1985; Krasniqi and Desai, 2017) had already suggested that uncertain and non-conducive domestic environment might act as a push factor encouraging firms to shift their attention to exporting. Firms which perceive their domestic environment as having fewer opportunities because of barriers to doing business such as macroeconomic instability, inefficient rule of law, high cost of financing or weak infrastructure, will tend to offset the perceived domestic market risks by exporting their new or significantly improved products to a relatively safer market.

Business environment also has a significant impact on firms' strategies, restructuring and behaviour (Becheikh et al., 2006; Krasniqi and Desai, 2016). This argument is in line with the contingency theory suggesting that an organisation is an adaptive system which progresses by reacting to its environment (Lawrence and Lorsch, 1967; Woodward, 1970). At the same time, the uncertain environment may negatively affect the generation of innovation (Teece, 1986). This view has not been considered in the later literature on innovation and export performance relationship (Wakelin, 1998; Sterlacchini, 1999; Roper and Love, 2002; Damijan et al., 2008; Gashi et al., 2014). A likely reason why these factors have not been accounted for is that most of the studies in this area have investigated developed economies where business environment is perceived as favourable and is not considered to be an issue. In the specific case of TEs which are still catching up with the developed economies, domestic business environment factors might be crucial to firm's performance. ${ }^{1}$ As argued by Dana and Dana (2003), funding by the developed economies to post-communist societies has resulted in the improvement of the infrastructure, but what TEs need to improve is a legal framework that creates an optimal level of regulation and government intervention, which is society-specific. Improvement of the institutional environment creates opportunities for an easier access to foreign markets and the development of internationally oriented entrepreneurs (Ratten et al., 2017). In the business environment context, institutional reforms of TEs are an important factor in their development in general and their export performance in particular.

The market oriented reforms in TEs and the stage of transition in the countries under consideration are discussed in the next section.

\subsection{Stages of transition reforms and export performance}

Although the former socialist countries in CEECs began the process of transition in the 1990-91 period, their initial conditions and patterns of development were not the same. They have all gone through similar phases of institutional and market-oriented reforms but at different points in time. Aiming to achieve a faster transition, they mainly followed 
the bing-bang approach that aimed for fast liberalisation of prices and privatisation of state firms (Kaynak and Dana, 2013). Nevertheless, various authors (Holger 1999; Damijan et al., 2015: among others) have highlighted the differences between these countries based on their progress to higher stages of transition. Damijan et al. (2015) argue that high export growth in absolute and relative terms has made export performance an outstanding feature of the transition process and the process of integration of CEECs in the EU. Havlik et al. (2001) emphasise that the competitive position of CEECs has generally improved in comparison to other non-EU competitors through their supply capacity. The low labour cost in the early stage of transition (Havlik, 2000) and the modification of export structure towards goods with higher value added (Damijan et al., 2015) at later stages of transition increased their market shares on foreign markets, especially in the EU-15.

The magnitude and significance of the factors affecting export performance is expected to vary between different stages of transition. The point made by Teece (1986) that the uncertain conditions under which firms may utilise the returns from innovation is a critical factor for innovation decisions becomes relevant. In general, the uncertainty about the future course of events in the early transition was bound to negatively affect the generation of innovation. TEs also lacked a strong infrastructure for innovation such as raising capital, hiring personnel or gaining knowledge of customer demand (Sofka and Grimpe, 2009). As Gurau and Dana (2010) argue, in the early transition the labour market was characterised by the availability of well-qualified specialists in some technical domains, but with a significant shortage of professionals prepared for a free-market economy. Therefore, firms could only engage in upgrading their products and processes mainly based on cost reduction rather than increasing the quality of products because of the limited access to advanced technology and R\&D capacities. Nevertheless, as they progressed to higher stages of transition, the relevance of these obstacles gradually decreased or disappeared. The evidence suggests that the average quality of goods produced by firms in CEECs has increased and competition strategy has moved to quality rather than price competition (Benkovskis and Wörz, 2012). At the same time, the nature of innovation activities has also changed, from minor upgrades and differentiation of traditional products based on low cost and low prices (Damijan et al., 2015 ) to higher level product and process innovation aimed at quality improvements.

The quality of institutions, an important feature of the transition process, has been shown to be an essential factor in growing export performance (Rodrik et al., 2004; Damijan et al., 2015). Kaminski et al. (1996, p.46) argue that “...establishment of market-supporting institutions was perhaps the single most important factor determining foreign trade performance over the transitional period." Further, Damijan et al. (2015) suggest that those CEECs which are more ambitious in their on-going structural reforms and the building of a stable institutional setup are more successful in fostering export growth. Gurau and Dana (2010) argue that most of the business barriers, such as bureaucracy, corruption, inflation, economic instability, lack of legal enforcement and lack of supporting services show a decreasing tendency in the later stages of transition. As Kaynak and Dana (2013) emphasise, the delays in the transition process are larger in countries where the ability of people to adapt is slower than the pace of institutional reforms. In general, the relationship between firm's innovation and export performance in TEs is likely to vary in different stages of transition. The next section reviews literature on the determinants of export performance at the firm level. 


\subsection{Determinants of export performance at the firm level}

This section reviews the literature on factors affecting export performance at the firm level.

\subsubsection{Innovation activities}

Innovation is found to have a positive and significant impact on the export performance in developed economies [Wagner (2001) for Germany, Wakelin, (1998), Roper and Love (2002) and Higon and Driffield (2011) for the UK] and (Sterlacchini, 1999; Sterlacchini, 2001 for Italy) as well as developing (Anh et al., 2009) and transitional countries (Halpern and Muraközy, 2012). For the UK, Pickernell et al. (2016) found that the focus of SMEs on innovation is positively linked to their exporting, while, using the number of innovations as the measure of innovation activities; Wakelin (1998) has shown that innovating and non-innovating firms in the UK are significantly different in terms of both probability of exporting and the level of exports. Some authors have found that only product innovation, but not process innovation, exerts a significant and positive impact on export performance (Becker and Egger, 2007; Cassiman and Golovko, 2007). Other authors have used R\&D intensity, the input measures of innovation activities, though this may provide misleading results as not all innovation inputs are converted to output (Brouwer and Kleinknecht, 1996; Roper and Love, 2002; Gerguri-Rashiti et al., 2017). In this study, we use innovation output indicators as measured by product and process innovation, which provide a more direct effect of firm's actual innovation activities, and as Gerguri-Rashiti et al. (2017) indicate, also a direct effect on firms' commercial success.

For TEs, innovation is considered one of the key factors to enhance competitiveness of firms in international markets (Kurtishi-Kastrati et al., 2016). For the case of Slovenia, Damijan et al. (2008) found a positive impact of innovation on firms' export intensity. Similar findings were reported for all TEs by Gashi et al. (2014). However, their analysis did not control for either the moderating effect of transition reforms stage or the impact of the degrees of product novelty on export performance. In general, the impact of innovation on export performance is expected to be positive.

\subsubsection{Business environment factors}

As discussed previously in Section 2.3, uncertainty and non-conducive business environment might on the one hand deter investment in innovation and, on the other hand, act as a mechanism pushing firms towards exporting as a risk balancing mechanism. Jalali (2012) found that political and economic conditions are found either to impede or to facilitate exporting. Faruq (2011) emphasises that an increased quality and effectivity of the rule of law institutions and the government can positively impact export growth. Furthermore, he finds that improvement in the institutional related factors can as well have a positive effect on the increase of export price of the manufactured products. Damijan et al. (2015) suggest that the real exchange rate, reflecting the macroeconomic environment of a country, is an important institutional variable affecting export performance. Uncertain domestic environment is found to have a positive impact on the export performance amongst Greek entrepreneurs (Dimitratos et al., 2004). Higon and Driffield (2011) found that the UK SMEs are more likely to shift their emphasis to 
exports if they perceive domestic competition to be an important barrier to their business. Besedes (2011) finds that the economic risk of a country matters to domestic exporters, indicating that firms located in countries with higher economic risk tend to export to countries with lower economic risk.

Nordas and Piermartini (2004) among others (see also Limao and Venables, 2001; Francois and Manchin, 2007) find that the quality of infrastructure has a positive impact on export performance. This is self-evident as better road infrastructure reduces the cost of transport, whereas a better communication system is expected to improve the efficiency of communication between trade partners. As Dana (2017) argues, low-cost telecommunications and better transportation have contributed to a higher tendency to export by all firms. The BEEPS dataset used in this paper provides information on business environment indicators based on the perceptions of firms' managers.

\subsubsection{Human capital}

The quality of a firm's stock of human capital is expected to affect its productivity, innovativeness and its export performance. One measure of this quality often used in the literature is the share of employees with higher education in total number of employees. Some authors have found a positive relationship between higher educated employees and export performance (Wakelin 1998; Wagner, 2001; Higon and Driffield, 2011) whereas others have reported negative relationships (Willmore, 1992; Ramstetter, 1999). Gashi et al. (2014) found a positive impact for the proportion of employees with university degree and while controlling for the proportion of skilled employees.

\subsubsection{Foreign ownership}

Being part of an international group can create advantages for firms in accessing resources such as finance, physical or human capital, advanced technology, better management practices, and better branding, marketing, and distribution (Roper et al., 2006; Krasniqi and Mustafa, 2016). Ramstetter (1999) suggests that multinational companies are more efficient in export markets as they tend to have better access to advanced production and technology and have better marketing networks and cooperation with international companies. Empirical results support the view that foreign owned firms are better export performers (Correa et al., 2007; Du and Girma, 2007).

\subsubsection{Networking}

Among other potential factors, the literature on export performance emphasises the role of external linkages or networking. Membership in trade associations is found to foster a firm's export performance (Higon and Driffield, 2011; Gashi et al., 2014). The evidence suggests that the limited access to information sources in the international markets and networks with businesses abroad might act as an obstacle to export performance (Rogers, 2004).

\subsubsection{Knowledge spillover effects}

Several types of knowledge spillover have been shown to affect firms' export performance. The agglomeration effect or the presence of exporters in the same region or industry is suggested to have a positive relationship with the industry share of exports 
(Lovely et al., 2005; Greenaway and Kneller, 2008). Firms located in urban areas have been found to have significantly better export performance than their counterparts in non-urban areas (Antonietti and Canielli, 2008). Due to higher interactions between businesses and academic and scientific institutions, the proximity to large cities and urban areas can lead to knowledge sharing and improved productivity at firm level.

Learning by importing is another type of knowledge spillover. If firms import some of their inputs, they will get more knowledge about state of technology and the products available in the international markets. Through their contacts with international suppliers, firms are expected to learn by importing and in turn might increase their export performance. Coe et al. (1997) found that knowledge spillover arising from R\&D activities in advanced countries have a significant impact on less developed countries, thus suggesting a knowledge spillover through trade relations. Drawing on BEEPS data, Gashi et al. (2014) found a positive and significant impact of import intensity on export performance of firms in CEECs. In addition, the production of innovation at the sector level is found to improve the probability of exporting by all firms, both innovative and non-innovative (Wakelin, 1998). Ramadani et al. (2017) finds that the knowledge spillovers have positive influence on the performance of firms in Balkan countries. The positive impact of knowledge spillover is expected to be larger in higher stages of transition reforms, since at higher stages of developing a full market economy firms are likely to have higher absorptive capacity for absorbing the new knowledge.

\subsubsection{Firm size}

In most studies (e.g., Wakelin, 1998; Sterlacchini, 1999; Roper and Love, 2002) the effect of firm size is found to be positive but non-linear. Verwaal and Donkers (2001) indicate that smaller firms may be more risk-averse, due to the lack of information and relatively greater impact of failure compared to larger firms. As larger the firms are they may have better access to various sources of finance (Ratten, 2006). As a result, larger firms are able to use benefits of specialisation in order to reduce the cost of their export operations and have better export performance. However, as firms become larger, they might prefer to enter export markets through foreign direct investments rather than exports (Cassiman and Martinez-Ros, 2007), suggesting a bell-shaped relationship between size and export performance.

\subsubsection{Age of the firm}

The firm's age as a proxy for its experience is also expected to affect export performance. For example, Dean et al. (2000) and Lado et al. (2004) report a significant and positive relationship between the firm's age and its export performance. Similarly, to the firm size effect, as firms get older and more experienced, they might accumulate more knowledge and enter exporting markets in other ways, such as through FDIs [Barba Navaretti and Venables, (2004), p.139; Krasniqi and Kutllovci, 2008).

\subsubsection{GDP per capita}

Lee and Huang (2002) argue that economic growth as a demand side factor promotes exports. Although one would expect that higher income or higher GDP per capita would increase domestic demand, and thus may decrease export. On the other hand, Lee and 
Huan argue that in growing economies, industries may grow in terms of innovation, human capital and the capacity to absorb knowledge, which enables them to have better export performance.

\section{Research methodology}

\subsection{Sample and data}

This paper uses the Business Environment and Enterprise Surveys (BEEPS) database undertaken jointly by the European Bank for Reconstruction and Development (EBRD) and the World Bank in many countries. The focus is on the dataset related to three rounds of surveys in years 2002, 2005 and 2008 in 29 TEs. Each survey is conducted in a random sample of around 30,000 firms and contains questions regarding the innovation activities of firms as well as the perceived impact of business environment factors. As explained by the EBRD, the survey examines the quality of the business environment through a wide range of interactions between firms and the state. The sample is selected randomly from the population of firms in manufacturing and services (including trade sector) and designed to be as representative of the population as possible. The sample is distributed between at least two major industrial regions within each country. The sectorial composition of firms in the survey is on the basis of different sectors' contribution to GDP of the country. The sample is stratified to ensure that at least $10 \%$ of firms in each country to be in the following categories: small, large, and foreign owned, and exporting.

Since BEEPS surveys are repeated each three years in random samples of companies, it is possible to pool them and work with a larger sample, provided that the questionnaires in respective surveys have a common methodology and contain the same questions. Wooldridge (2006, p.10) emphasises that pooling of random samples drawn in different time periods produces independently pooled cross sections which increases the sample size and enables getting more precise estimators and more powerful test statistics. Since the investigation of TEs is based on their reforming stage and involves splitting the sample into three sub-samples, the number of observations in each sub-sample would be rather small to have robust results if we were to rely on individual surveys. However, the relevant questions of interest are similar only for BEEPS2002 and BEEPS2005, whereas some of the questions of interest for this research were excluded in BEEPS 2008. Therefore, BEEPS2002 and BEEPS2005 are pooled together, and hereafter will be referred to as POOLED2 dataset, while the three datasets (the previous two plus BEEPS 2008) are also pooled together and hereafter will be referred to as POOLED3 dataset.

\subsection{Definition of stages of transition}

In its annual Transition Report, the EBRD produces annual assessment of 'progress in transition reforms' for different aspects of reforms for all countries using its own methodology based on the judgement of its economists. A simple average of these indicators is constructed, as the transition index, to measure the overall level of reforms in each country for each year. Several authors have used these indices for the purposes of ranking of institutional reforms in different countries (e.g., Falceti et al., 2005). ${ }^{2}$ 
Table 1 Transition economies by the stage of transition

\begin{tabular}{|c|c|c|c|}
\hline \multirow{2}{*}{$\begin{array}{l}\text { Transition } \\
\text { stage }\end{array}$} & \multicolumn{3}{|c|}{ Transition economies by the stage of transition for years 2002, 2005 and 2008} \\
\hline & 2002 & 2005 & 2008 \\
\hline $\begin{array}{l}\text { SLOW } \\
\text { reforming }\end{array}$ & $\begin{array}{c}\text { Azerbaijan, Belarus, } \\
\text { Bosnia and Hercegovina, } \\
\text { Montenegro, Serbia, } \\
\text { Tajikistan, Turkmenistan, } \\
\text { Uzbekistan }\end{array}$ & $\begin{array}{l}\text { Azerbaijan, Belarus, } \\
\text { Bosnia and } \\
\text { Hercegovina, } \\
\text { Montenegro, Serbia, } \\
\text { Tajikistan, } \\
\text { Turkmenistan, } \\
\text { Uzbekistan }\end{array}$ & $\begin{array}{c}\text { Azerbaijan, Belarus, } \\
\text { Tajikistan, Turkmenistan, } \\
\text { Uzbekistan }\end{array}$ \\
\hline $\begin{array}{l}\text { MEDIUM } \\
\text { reforming }\end{array}$ & $\begin{array}{c}\text { Albania, Armenia, } \\
\text { Bulgaria, Croatia, } \\
\text { Georgia, Kazakhstan, } \\
\text { Kyrgyz Republic, Latvia, } \\
\text { Macedonia, Moldova, } \\
\text { Romania, Russian } \\
\text { Federation, Slovenia, } \\
\text { Ukraine }\end{array}$ & $\begin{array}{c}\text { Albania, Armenia, } \\
\text { Bulgaria, Croatia, } \\
\text { Georgia, Kazakhstan, } \\
\text { Kyrgyz Republic, } \\
\text { Macedonia, Moldova, } \\
\text { Romania, Russian } \\
\text { Federation, Slovenia, } \\
\text { Ukraine }\end{array}$ & $\begin{array}{l}\text { Albania, Armenia, } \\
\text { Bulgaria, Bosnia and } \\
\text { Herzegovina, Croatia, } \\
\text { Georgia, Kazakhstan, } \\
\text { Kyrgyz Republic, } \\
\text { Macedonia, Moldova, } \\
\text { Mongolia, Montenegro, } \\
\text { Romania, Russian } \\
\text { Federation, Serbia, } \\
\text { Slovenia, Ukraine }\end{array}$ \\
\hline $\begin{array}{l}\text { FAST } \\
\text { reforming }\end{array}$ & $\begin{array}{l}\text { Czech Republic, Estonia, } \\
\text { Hungary, Lithuania, } \\
\text { Poland, Slovak Republic }\end{array}$ & $\begin{array}{l}\text { Czech Republic, } \\
\text { Estonia, Hungary, } \\
\text { Latvia, Lithuania, } \\
\text { Poland, Slovak } \\
\text { Republic }\end{array}$ & $\begin{array}{c}\text { Czech Republic, Estonia, } \\
\text { Hungary, Latvia, } \\
\text { Lithuania, Poland, Slovak } \\
\text { Republic }\end{array}$ \\
\hline
\end{tabular}

Source: Authors' own classification based on EBRD transition indices

The specification of the stages of transition follows EBRD's transition gap scores. ${ }^{3}$ Based on these scores indicating the thresholds of each stage; three clusters of countries are identified (fast, medium and slow reformers). Fast reforming countries are considered countries which score above 3.7 on the EBRD transition index, or countries with a small to negligible transition gap covering scores of 4-, 4 and 4+. Medium reforming countries are those scoring from 3 to 3.7 , or countries with a medium to small transition gap, whereas slow reforming countries are those with a large to medium transition gap, with scores less than three in the overall transition index. Using this methodology, the transition countries under consideration fall in three clusters presented in the Table 1.

It is clear from the above table that with few exceptions, the clusters of countries in different stages of transition have remained unchanged. A few countries have managed to speed up their reforms and move from the slow to medium some reforming stage or from medium to fast reforming stage over the three periods.

\subsection{Model and variables}

The investigation of the export performance at the firm level has generally been addressed in a twofold approach, examining both the decision to export (export propensity) and the amount exported (export intensity) by a firm (Wakelin, 1998; Sterlacchini, 1999, 2001; Roper and Love, 2002; Ozçelik and Tamyaz, 2004). As Gashi et al. (2014) argue, export behaviour is determined by the interplay of explanatory factors which mainly affect productivity level and the fixed costs, with same factors affecting 
both the firm's export propensity and export intensity. The inclusion of exporters and non-exporters in a joint model is made possible by the nature of the available data. The firm level survey includes both exporters and non-exporters, with a proportion of firms having reported $0 \%$ for exports. According to Wooldridge $(2006$, p.598) in cases when there is a population distribution spread out over a range of positive values, but with a considerable proportion of observations being 0 , undertaking OLS estimation would lead to negative predictions for some of the firms. When the optimal value of a variable is zero (in this case exports) for a nontrivial fraction of firms, the Tobit model becomes the appropriate estimation model. Export performance is expressed as a function of the firm's internal and contextual factors which are further specified in the following section (Ozçelik and Tamyaz, 2004; Anon Higon and Driffield, 2011; Gashi et al., 2014).

The Tobit model of export performance can be expressed as:

$$
\begin{aligned}
& y_{i}=\left\{\begin{array}{ccc}
y_{i}^{*}=\beta x_{i}+\varepsilon_{i} & \text { for exporters } & \text { if } \beta x_{i}+\varepsilon_{i}>0 \\
0 & \text { for non-exporters } & \text { otherwise }
\end{array}\right. \\
& \varepsilon_{i} \sim N\left(0, \sigma^{2}\right)
\end{aligned}
$$

$y_{i}$ can be observed only through the latent variable in cases when its value is positive $\left(y_{i}^{*}>0\right)$, but when $y_{i}^{*} \leq 0$, the dependent variable cannot be observed. $x_{i}$ is the vector of independent variables, $\beta_{i}$ the coefficients of the variables and the intercept, and $\varepsilon_{i}$ is the error term with a normal and homoskedastic distribution and a linear conditional mean [Wooldridge, (2006), p.596]. The dependent variable in the model is the proportion of sales coming from exports (the sum of direct and indirect export sales divided by total sales) expressed in percentages. The main independent variables are innovation output measures and business environment related factors. New products, upgraded products and process innovation are used as three measures of innovation (all in the form of dummies). The dummies take the value of one if firms have introduced any new products or processes or has upgraded existing products in 36 months prior to the survey, otherwise zero. While information on product innovation is available in all survey rounds, that on process innovation is available only in BEEPS 2002 and BEEPS 2005 datasets. The two-way relationship between innovation and export performance as hypothesised by the new growth theory (Grossman and Helpman, 1994) will not be a problem here because the innovation variable is a lagged value reflecting the introduction of innovation (both product and process) 36 months prior to the survey, whereas export intensity is given for the current survey period.

The surveys contain questions on a large number of business environment obstacles. These obstacles have been put into four main groupings and dummy variables have been constructed on the basis of the perception of entrepreneurs. ${ }^{4}$ The four group of variables are macroeconomic instability (consisting of indicators for inflation, exchange rate or uncertainty about regulatory policies), infrastructure (consisting of indicators for telecommunication, transportation or electricity indicators), access to finance (consisting of indicators for cost of finance or access to finance indicator), and the weakness of the rule of law (consisting of indicators for anticompetitive behaviour and unfair competition by competitors) ${ }^{5}$

Table 2 reports detailed description of variables used in the estimation process and their descriptive statistics for all three rounds of the survey. 
Innovation and the export performance of firms in transition economies

Table 2 Description of variables and descriptive statistics BEEPS 2002/BEEPS 2005/BEEPS 2008

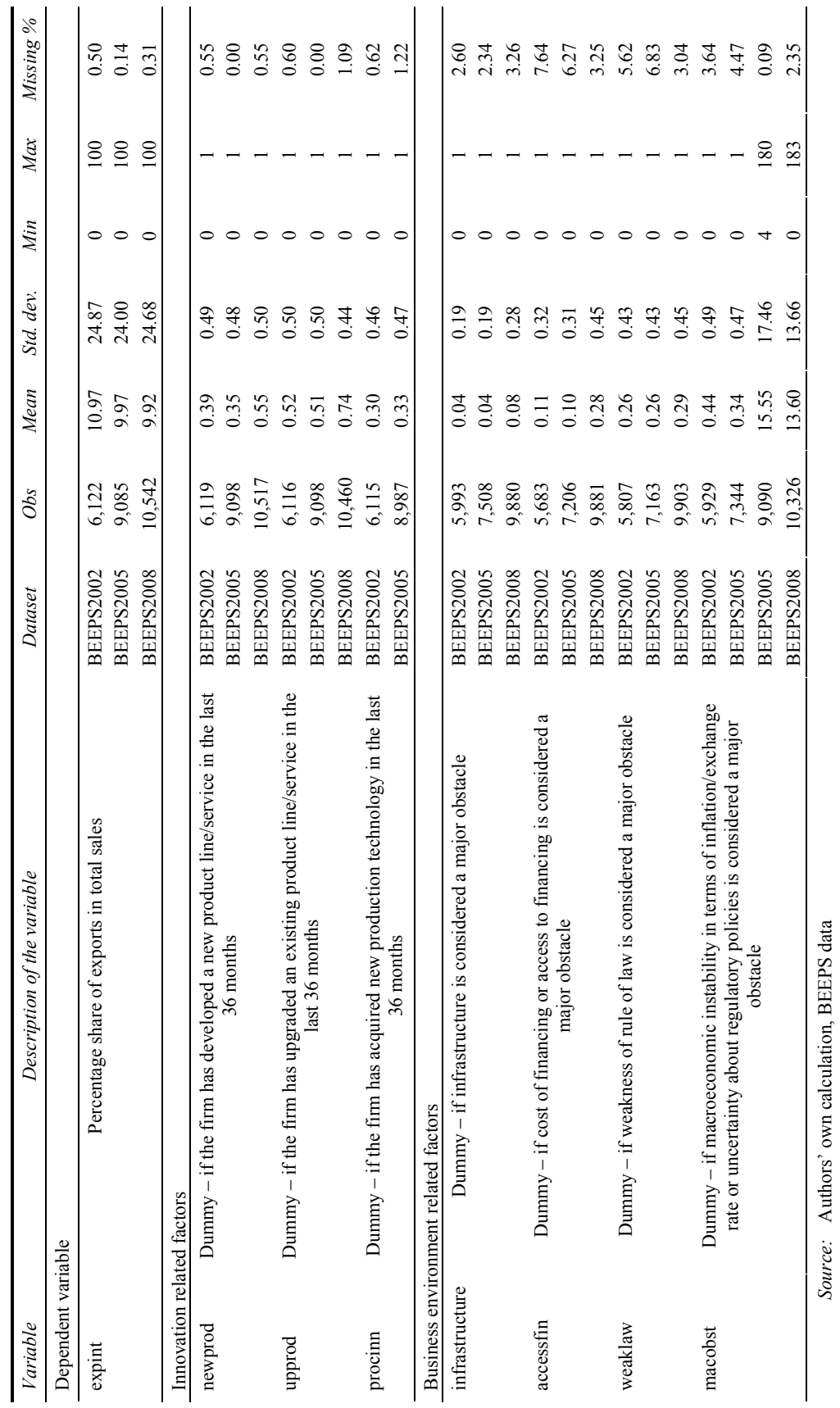


$14 \quad$ F. Reçica et al.

Table 2 Description of variables and descriptive statistics BEEPS 2002/BEEPS 2005/BEEPS 2008 (continued)

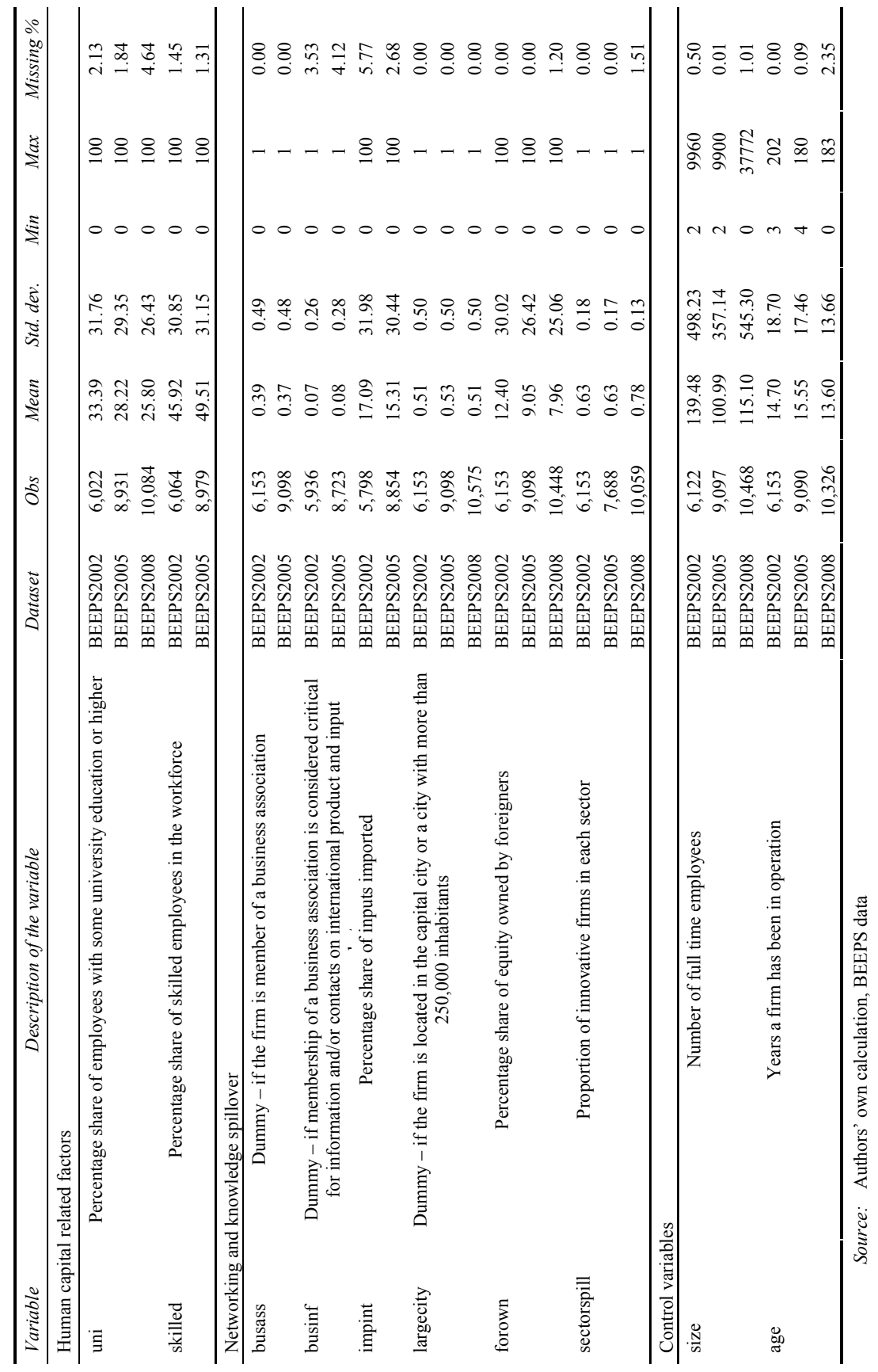




\section{Findings}

This section discusses estimation diagnostics and the estimated model for each dataset and each stage of transition reforms.

\subsection{Estimation diagnostics}

To test for the appropriateness of the Tobit model, the informal test suggested by Wooldridge (2006) has been undertaken. Coefficients from Tobit estimates have been divided by Tobit sigma and then compared with coefficients from a Probit estimation. Insignificant differences between the two suggest that same factors influence both the propensity to export and export intensity of firms in TEs. Second, following Wooldridge (2006), the Chow test is used to check for the homogeneity between subsamples in the pooled datasets. Its results indicate that there are no structural differences between subsamples in the pooled datasets. ${ }^{6}$ Third, to test the rationale for splitting the overall sample into subsamples based on the transition stage; an F-test is undertaken. At a 1\% level of statistical significance, there is sufficient evidence to reject the null hypothesis that the parameters of the three groups are the same, thus supporting the rationale for splitting the survey data into three subgroups o fast, medium, and slow reforming countries. Fourth, there is no correlation problem between independent variables (see the correlation matrix in Table A1 in the Appendix). Finally, the specification issue arising from the use of aggregate variables (country or sector) in a micro model has been addressed. This is because the sectorial knowledge spillovers and GDP per capita are included in the estimated model at the sector and country level, empirical estimation requires caution when specifying the model due to potential sector level and country level invariant effects. Here, as Moulton (1990) emphasises, standard errors have to be adjusted in order to avoid errors in variables, omitted variable bias and even aggregation issues. Standard errors have been adjusted by controlling for sectorial clusters, whereas invariant country effects are controlled by including country dummies in the Tobit estimation for both pooled estimations.

\subsection{Estimation results}

The Tobit model has been estimated for the two datasets (POOLED2 and POOLED3), with three sub-samples each. Table 3 shows the results of these estimations. Of course, as Wooldridge (2002, p.527) points out, the coefficients in Tobit estimations cannot be directly interpreted and, for this reason, the unconditional marginal effects have been produced and presented in Table A2 in the Appendix. Here we will discuss the findings only in terms of sign and significance. To identify the impact of individual variables on export performance, Table A2 should be consulted.

In general, the sign and significance estimated coefficients are in accordance with a priori expectation and consistent between different datasets, indicating the robustness of these results. Given that the results for the two datasets (POOLED2 and POOLED3) are largely the same, we discuss the results for only one of them. 


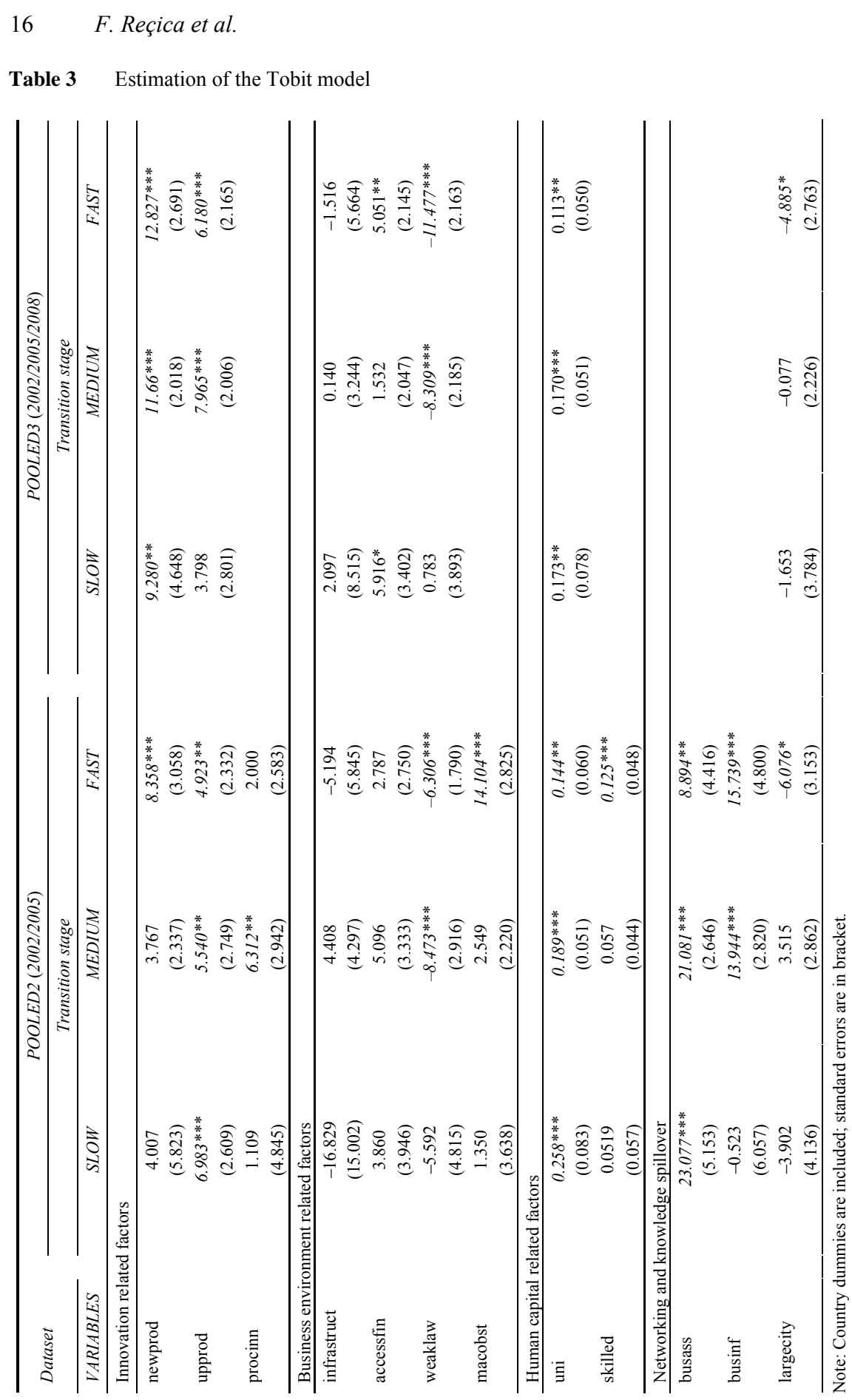


Innovation and the export performance of firms in transition economies

Table 3 Estimation of the Tobit model (continued)

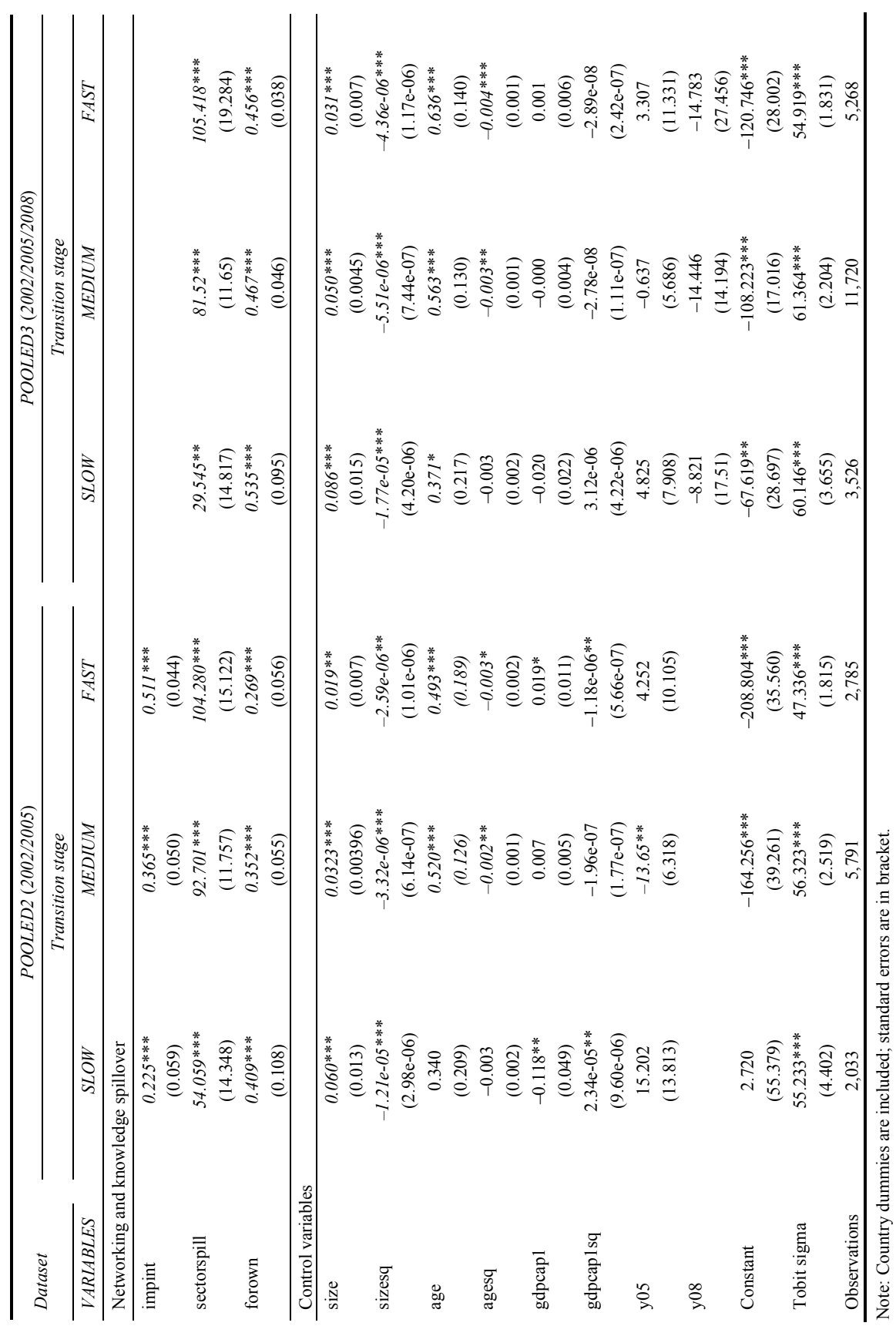




\subsubsection{Innovation related variables}

Results from the estimations using the three-survey database (POOLED3) support the hypothesis that new products, and also upgraded products, have a significant impact on firm export performance. Unconditional marginal effects (Table A2 in the Appendix) increase slightly in higher stages of transition. The marginal effects also show that the impact of this factor is fairly small (between 2.4 to $3.9 \%$ between lower transition and higher stages of transition). The coefficients are also higher for new products than for upgraded products. In line with other studies (Becker and Egger, 2007; Cassiman and Golovko, 2007) process innovation appear to be significant only in medium transition stage.

In general, it seems that the impact of innovation on export performance is moderated by the stage of transition reforms. As countries move to higher stages of transition to a market economy, the introduction of new products becomes a more significant factor affecting their export performance. This is in line with the suggestion of Damijan et al. (2015) that by changing towards goods with higher value added, CEECs have increased their share of foreign markets. But in the early stages of transition, as Lall (2000) argues, they might be more likely to rely on cost reducing strategies. Hence, public policies in CEECs should support innovation related processes which lead to introduction of new products by firms, especially in countries at a more advanced stage of transition.

Because the comparison of results across different estimations is not straightforward, for a robustness check and to provide additional confirmation on the comparative effects of innovation on export performance across the stages of transition, we undertake an alternative Tobit estimation for the whole sample using an interaction term combining the innovation related variable and a stage of transition variable. For the latter we use both the EBRD transition index with scores ranging from 1 to 4.3 . And, alternatively, as a categorical variable expressing the transition stages as per the three respective transition groupings defined earlier in this chapter: 1 for Laggard; 2 for Medium; and 3 for the advanced stage of transition. To explore the effect of the interaction terms we calculate Tobit unconditional marginal effects of innovation variables on export performance per each stage of transition using the 'margins' command.

The Tobit unconditional marginal effects show that, when interacting innovation related variables with the stage of transition, the effect of innovation related variables (newprod and upprod) increases across the stages of transition and their size is similar to the estimated effects for the three groupings of countries separately (laggard, medium and advanced reforming countries), confirming the robustness of our findings (comparative results across subsamples) and the chosen estimation approach (For the sake of brevity, we present the graphical presentation of the marginal effects, 'marginsplot', in Appendix A1, Figures A1-A5).

\subsubsection{Business environment related factors}

The impact of different business environment factors is different. The weak rule of law has a negative effect on export performance in medium and fast reforming TEs but macroeconomic instability, as explained earlier, can encourage firms in countries at higher stages of transition to shift their emphasis on foreign markets and improve their export performance. Access to finance is insignificant in some specifications but also 
positive in two specifications. The infrastructure variable is insignificant in all regressions. $^{7}$

\subsubsection{Human capital related indicators}

The share of employees with university degree or higher has a significant positive impact in all stages of transition and all specifications. However, the share of skilled employees appears significant only in the higher stage of transition. This implies that the effectivity of skilled employees, as well as the quality of professional education, increases when countries reach higher level of transition reforms.

\subsubsection{Networking and knowledge spillover related variables}

Being member of a business association shows a significant and positive impact on export performance in all stages of transition. Similarly, sectorial knowledge spillover appears positive and statistically significant in all specifications. Knowledge spillover from imports too is significant and positive in all stages of transition. These findings are in line with previous research that firms benefit from innovation activities in their sector (Wakelin, 1998; Roper and Love, 2002). Location in large cities and the capital (or agglomeration economies) is mostly insignificant and in two specifications negative and significant. It seems that firms located in large and capital cities may have more access to their local market and might be less inclined towards export markets. Finally, in line with the previous research (Correa et al., 2007; Du and Girma, 2007), the impact of foreign ownership appears positive and statistically significant in all stages of transition.

In terms of control variables, firm size shows to be significant and positive, as expected, in almost all transition stages, whereas its squared value is negative and statistically significant. This outcome suggests an inverse U-shaped relationship between size and export performance in all stages of transition. The same inverse U-shaped relationship, though somewhat weaker, is found for age. These results support the view that when firms grow bigger or become more experienced then they might choose alternative methods of entry into foreign markets (e.g., FDI). In terms of domestic demand factors, the paper finds that an increase of GDP per capita has a negative and statistically significant effect on export only in the slow transition stage. The opposite effect of GDP per capita is found for fast growing countries. The findings indicate that the argument of Lee and Huang (2002) is partially supported and depends on the stage of development in a country.

\section{Conclusions and implications}

Drawing on the BEEPS cross-section data for the years 2002, 2005 and 2008, this paper highlighted the factors affecting export performance of firms in TEs going through three stages of transition reforms. Empirical findings indicate that the impact of some explanatory factors differs in the three stages of transition. This in turn suggests that generalisation of results of empirical studies on export performance to countries at different stages of transition may be inappropriate. There is no universal recipe for TEs, but export performance depends on the context which differs at different stages of transition. Thus, policymakers should take into account that the effect of each individual 
explanatory factor on firm's export performance can vary across different stages of transition.

Innovation activities, measured by the introduction of new and upgraded products/services were shown to have a positive and significant impact on export performance, more strongly at higher stages of transition. The effect was somewhat stronger for new products rather than an upgraded product, i.e., the degree of product novelty seems to be important. On the other hand, process innovation seems to be an important factor only in the intermediate stage of transition. Findings imply that in countries at more advanced stage of transition, governments should facilitate the introduction of product innovation at the firm level by designing incentive based mechanisms that will increase the engagement of firms in the introduction of new products. On the other hand, facilitating the introduction of incremental innovation or supporting firms to upgrade their products is likely to be effective in countries lagging behind with transition reforms.

In terms of uncertainty in the business environment, if firms perceive that there is macroeconomic instability, in countries at high transition stage, then they tend to export more, as a risk shifting mechanism. On the other hand, other business environment factors such as the weakness of the rule of law exert a negative and significant impact on firm's export performance in countries at medium and high stage of transition. In slow reforming countries, these factors are likely not to have a significant impact of firms' exports. Furthermore, the quality of the infrastructure does not seem to have a significant impact on export performance. While the business environment factors do not seem significantly important to slow reforming countries, a particular attention to these related factors should be given by policymakers in the medium and high reforming countries.

In terms of human capital related factors, the impact of university education is positive in all specifications while the impact of employee skills becomes significant only at higher stages of transition. This implies that governments should facilitate the improvement of higher education in transition countries, and support vocational education when countries advance with transition reforms.

There are productivity spillovers from networking, being in an industry with more innovative firms and importing inputs from abroad no matter of the stage of transition. Similarly, and in line with previous findings, the share of foreign ownership is found to have a significant and positive impact in all specifications and through all stages of transition. In this regard, facilitating sectoral technological spillovers and firms' access to information on international markets, and encouraging foreign investment should be undertaken in all TEs throughout the whole transition period.

Larger and more experienced firms are likely to have better export performance though the relationship is a non-linear one, an inverted U-shaped throughout all transition stages. In terms of the demand side factors, the effect of GDP per capita on firm's export performance is dependent on the degree of transition reforms. An increase of GDP per capita in slow reforming countries is likely to decrease firm's exports but has a contrary effect in higher reforming countries.

Finally, the paper has some limitations. The BEEPS data is based on subjective opinions of firm managers, which requires cautious interpretation. Notwithstanding, the large number of observations tends to increase the precision of results. Second, as this study draws on cross section data, it does not capture dynamic lagging effect of innovation on export performance. Future studies should consider using panel data and controlling for the impact of institutional quality on export performance of firms. 


\section{References}

Anh, N.N., Jones, N., Nhat, N.D. and Chuc, N.D. (2009) 'Capitalising on innovation for exports by the SME sector', Working paper series No: 2009/15, DEPOCEN - Development and Policies Research Centre.

Anon Higon, D. and Driffield, N. (2011) 'Exporting and innovation performance: analysis of the annual small business survey in the UK', International Small Business Journal, Vol. 29, No. 1, pp.4-24.

Antonietti, R. and Cainelli, G. (2008) 'Spatial agglomeration, technology and outsourcing of knowledge intensive business services. Empirical insights from Italy', International Journal of Services Technology and Management, Vol. 10, Nos. 2-4, pp.273-298.

Barba Navaretti, G. and Venables, A.J. (2004) Multinational Firms in the World Economy, Princeton University Press, Princeton.

Becheikh, N., Rejean, L. and Amara, M. (2006) 'Lessons from innovation empirical studies in the manufacturing sector: a systematic review of the literature from 1993-2004', Technovation, Vol. 26, Nos. 5-6, pp.644-664.

Becker, S. and Egger, P. (2007) Endogenous Product versus Process Innovation and a Firm's Propensity to Export, CESIFO Working Paper No. 1906.

Benkovskis, K. and Wörz, J. (2012) 'Evaluation of non-price competitiveness in exports from Central, Eastern and South-Eastern European countries at the EU market', Workshop on external competitiveness and export performance, EC - Economic and Financial Affairs, Brussels, 27-28 March.

Besedes, T. (2011) 'Export differentiation in transition economies', Economic Systems, Vol. 35, No. 1, pp.25-44.

Brouwer, E. and Kleinknecht, A. (1996) 'Determinants of innovation: a microeconometric analysis of three alternative innovation output indicators', in Kleinknecht, A. (Ed.): Determinants of Innovation: The Message from New Indicators, Macmillan, London and Basingstoke.

Caldera, A. (2009) Innovation and Exporting: Evidence from Spanish Manufacturing Firm, ECARES Working paper No. 2009-014.

Cassiman, B. and Golovko, E. (2007) 'Innovation and the export-productivity link', IESE Research Papers D/688, IESE Business School.

Cassiman, B. and Martinez-Ros, R. (2007) 'Product innovation and exports. Evidence from Spanish manufacturing', IESE Business School, Mimeo, Barcelona.

Coe, D.T., Helpman, E. and Hoffmaister, A.W. (1997) 'North-South R\&D spillovers', Economic Journal, Vol. 107, No. 440, pp.134-49.

Cooper R.G. and Kleinschmidt, E.J. (1985) 'The impact of export strategy on export sales performance', Journal of International Business Studies, Vol. 16, No. 1, pp.37-55.

Correa, P., Dayoub, M. and Francisco, M. (2007) Identifying Supply-Side Constraints to Export Performance in Ecuador: An Exercise with Investment Climate Survey Data, World Bank Policy Research Working Paper, 4179.

Damijan, J., Kostevc, Č. and Rojec, M. (2015)' Bright past, shady future? Past and potential future export performance of CEE countries in a comparative perspective', Post-Communist Economies, Vol. 27, No. 3, pp.306-335.

Damijan, J.P., Kostevc, Č. and Polanec, S. (2008) From Innovation to Exporting or Vice Versa? Causal link between Innovation Activity and Exporting in Slovenian Microdata, LICOS Discussion Paper No. 204/2008.

Dana, L.P. (2017) 'International entrepreneurship research: how it evolved and directions for the future', International Journal of Entrepreneurship and Small Business, Vol. 30, No. 4 pp.477-489.

Dana, L.P. and Dana, T. (2003) 'Management and enterprise development in post-communist economies', International Journal of Management and Enterprise Development, Vol. 1, No. 1, pp.45-54. 
Dana, L.P., Grandinetti, R. and Mason, M.C. (2016) 'International entrepreneurship, export planning and export performance: evidence from a sample of winemaking SMEs', International Journal of Entrepreneurship and Small Business, Vol. 29, No. 4, pp.602-626.

Dean, D., Menguc, B. and Myers, C.P. (2000) 'Revisiting firm characteristics, strategy, and export performance relationship: a survey of the literature and an investigation of New Zealand small manufacturing firms', Industrial Marketing Management, Vol. 29, No. 5, pp.461-477. Development Studies, Vol. 28, No. 5, pp.314-335.

Dimitratos, P., Lioukas, S. and Carter, S. (2004) 'The relationship between entrepreneurship and international performance: the importance of domestic environment', International Business Review, Vol. 13, No. 1, pp.19-41.

Du, J. and Girma, S. (2007) 'Finance and firm export in China', Kyklos, Vol. 60, No. 1, pp.37-54.

Falceti, E., Lysenko, T. and Sanfey, P. (2005) Reforms and Growth in Transition: Re-Examining the Evidence, Working Paper No. 90, European Bank for Reconstruction and Development.

Faruq, Q. (2011) 'How institutions effect export quality', Economic Systems, Vol. 35, No. 4, pp.586-606.

Francois, J.F. and Manchin, M. (2007) Institutions, Infrastructure and Trade. Centro Studi Luca d'Agliano, Development Studies Working Paper No. 224 [online] http://ssrn.com/abstract= 964209 (accessed 10 February 2014).

Gashi, P., Hashi, I. and Pugh, G. (2014) 'Export behaviour of SMEs in transition countries', Small Business Economics, Vol. 42, No. 2, pp.407-435.

Gerguri-Rashiti, S., Ramadani, V., Abazi-Alili, H., Dana, L.P. and Ratten, V. (2017) 'ICT, innovation and firm performance: the transition economies context', Thunderbird International Business Review, Vol. 59, No. 1, pp.93-102.

Greenaway, D. and Kneller, R. (2008) 'Exporting, productivity and agglomeration', European Economic Review, Vol. 52, No. 5, pp.919-939.

Grossman, G.M. and Helpman, E. (1994) 'Endogenous innovation in the theory of growth', Journal of Economic Perspectives, Vol. 8, No. 1, pp.23-44.

Gurau, C. and Dana, L.P. (2010) 'The evolution of entrepreneurship forms and strategies in transition economies: the case of Romania', International Journal of Entrepreneurship and Small Business, Vol. 10, No. 1, pp.131-147.

Halpern, L. and Muraközy, B. (2012) 'Innovation, productivity and exports: the case of Hungary', Economics of Innovation and New Technology, Vol. 21, No. 2, pp.151-173.

Hashi, I. and Krasniqi, B.A. (2011) 'Entrepreneurship and SME growth: evidence from advanced and laggard transition economies', International Journal of Entrepreneurial Behavior \& Research, Vol. 17, No. 5, pp.456-487.

Havlik, P. (2000) Trade and Cost Competitiveness in the Czech Republic, Hungary, Poland and Slovenia, World Bank Technical Paper No. 482, World Bank, Washington, DC.

Havlik, P., Landesmann, M. and Stehrer, R. (2001) Competitiveness of CEE Industries: Evidence from Foreign Trade Specialization and Quality Indicators, WIIW Research Reports No. 278. Vienna: The Vienna Institute for International Economic Studies.

Higon, D.A. and Driffield, N. (2011) 'Exporting and innovation performance: analysis of the annual small business Survey in UK', International Small Business Journal, Vol. 29, No. 4. DOI: $10.1177 / 0266242610369742$.

Holger, W. (1999) Transition Strategies: Choices and Outcomes, Princeton Studies in International Finance, No. 85, Princeton University.

Jalali, S.H. (2012) 'Export barriers and export performance: empirical evidences from the commercial relationship between Greece and Iran', South-Eastern Europe Journal of Economics, Vol. 10, No. 1, pp.65-78.

Johanson, J. and Vahlne, J. (1977) 'The internationalization process of the firm: a model of knowledge development and increasing foreign market commitments', Journal of International Business Studies, Vol. 8, No. 1, pp.23-32. 
Kaminski, B., Wang, Z.K. and Winters, L.A. (1996) Foreign Trade in the Transition: The International Environment and Domestic Policy, Studies of Economies in Transformation, No. 20, World Bank, Washington, DC.

Kaynak, E. and Dana, L.P. (2013) When Economies Change Hands: A Survey of Entrepreneurship in the Emerging Markets of Europe from the Balkans to the Baltic States, Routledge, New York, USA.

Krasniqi, B.A. and Desai, S. (2016) 'Institutional drivers of high-growth firms: country-level evidence from 26 transition economies', Small Business Economics, Vol. 47, No. 4, pp.1075-1094.

Krasniqi, B.A. and Desai, S. (2017) 'Institutions and export performance in 26 transition economies', in Entrepreneurship in Transition Economies, pp.57-73, Springer International Publishing, Basel, Switzerland.

Krasniqi, B.A. and Kutllovci, E.A. (2008) 'Determinants of innovation: evidence from Czech Republic, Poland and Hungary', International Journal of Technoentrepreneurship, Vol. 1, No. 4, pp.378-404.

Krasniqi, B.A. and Mustafa, M. (2016) 'Small firm growth in a post-conflict environment: the role of human capital, institutional quality, and managerial capacities', International Entrepreneurship and Management Journal, Vol. 12, No. 4, pp.1165-1207.

Krugman, P. (1979) 'A model of innovation, technology transfer, and the world distribution of income', Journal of Political Economy, Vol. 87, No. 2, pp.253-266.

Kurtishi-Kastrati, S., Ramadani, V., Dana, L.P. and Ratten, V. (2016) 'Do foreign direct investments accelerate economic growth? The case of the Republic of Macedonia', International Journal of Competitiveness, Vol. 1, No. 1, pp.71-98.

Lado, N., Martinez-Ros, E. and Valenzuela, A. (2004) 'Identifying successful marketing strategies by export regional destination', International Marketing Review, Vol. 21, No. 6, pp.573-597.

Lall, S. (2000) 'The technological structure and performance of developing country manufactured exports, 1985-98, Oxford Development Studies', Taylor \& Francis Journals, Vol. 28, No. 3 pp.337-369.

Lawrence, P.R. and Lorsch, J.W. (1967) Organization and Environment: Managing Differentiation and Integration, Division of Research, Graduate School of Business Administration, Harvard University, Boston.

Lee, C.H. and Huang, B.N. (2002) 'The relationship between exports and economic growth in East Asian Countries: a multivariate threshold autoregressive approach', Journal of Economic Development, Vol. 27, No. 2, pp.45-68.

Limao, N. and Venables, A.J. (2001) 'Infrastructure, Geographical disadvantage, transport costs and trade', World Bank Economic Review, Vol. 15, No. 3, pp.451-479.

Lööf, H., Larijani, P.N., Cook, G. and Johansson, B. (2015) 'Learning-by-exporting and innovation strategies', Economics of Innovation and New Technology, Vol. 24, Nos. 1-2, pp.52-64.

Lovely, M.E., Rosenthal, S.S. and Sharma, S. (2005) 'Information, agglomeration, and the headquarters of US exporters', Regional Science and Urban Economics, Vol. 35, No. 2, pp.167-191.

Melitz, M. (2003) 'The impact of trade on intra-industry reallocations and aggregate industry productivity', Econometrica, Vol. 71, No. 6, pp.1695-1725.

Moulton, M.R. (1990) 'An illustration of the pitfall in estimating the effects of aggregate variables on micro units', Review of Economics and Statistics, Vol. 72, No. 2, pp.334-338.

Nordas, H.K. and Piermartini, R. (2004) Infrastructure and Trade, World Trade Organization Staff Working Paper ERSD-2004-04.

Ozçelik, E. and Taymaz, E. (2004) 'Does innovativeness matter for competitiveness in developing countries? The case of Turkish manufacturing industries', Research Policy, Vol. 33, No. 3, pp.409-424. 
Pickernell, D., Jones, P., Thompson, P. and Packham, G. (2016) 'Determinants of SME exporting: Insights and implications', The International Journal of Entrepreneurship and Innovation, Vol. 17, No. 1, pp.31-42.

Ramadani, V., Abazi-Alili, H., Dana, L.P., Rexhepi, G. and Ibraimi, S. (2017) 'The impact of knowledge spillovers and innovation on firm performance: findings from the Balkans countries', International Entrepreneurship and Management Journal, Vol. 13, No. 1, pp.299-325.

Ramstetter, E. (1999) 'Trade propensities and foreign ownership shares in Indonesian manufacturing', Bulletin of Indonesian Economic Studies, Vol. 35, No. 2, pp.43-66.

Ratten, V. (2006) 'Policy drivers of international entrepreneurship in Europe', Euromed Journal of Business, Vol. 1, No. 2, pp.15-28.

Ratten, V., Dana, L.P. and Ramadani, V. (2017) 'Internationalisation of family business groups in transition economies', International Journal of Entrepreneurship and Small Business, Vol. 30, No. 4, pp.509-525.

Rodrik, D., Subramanian, A. and Trebbi, F. (2004) 'Institutions rule: the primacy of institutions over geography and integration in economic development', Journal of Economic Growth, Vol. 9, No. 2, pp.131-165.

Rogers, M. (2004) 'Networks firm size and innovation', Small Business Economics, Vol. 22, No. 2, pp.141-153.

Romer, D. (1990) 'Endogenous technological change', The Journal of Political Economy, October, Vol. 98, No. 5, pp.219-239.

Roper S., Love J.H. and Higon, D.A. (2006) 'The determinants of export performance: evidence for manufacturing plants in Ireland and Northern Ireland', Scottish Journal of Political Economy, Vol. 53, No. 5, pp.586-615.

Roper, S. and Love, J.H. (2002) 'Innovation and export performance: evidence form UK and German Manufacturing Plants', Research Policy, Vol. 32, No. 7, pp.1087-1102.

Salomon, R.M. and Shaver, J.M. (2005) 'Learning by exporting: new insights from examining firm innovation', Journal of Economics and Management Strategy, Vol. 14, No. 2, pp.431-460.

Sofka, W. and Grimpe, Ch. (2009) Searching for Innovation in Market and Transition Economies: Evidence across Europe, Discussion Papers 09061, ZEW - Zentrum für Europäische Wirtschaftsforschung/Center for European Economic Research.

Sterlacchini, A. (1999) 'Do innovative activities matter to small firms in non-R\&D intensive industries? An application to export performance', Research Policy, Vol. 28, No. 8, pp.819-832.

Sterlacchini, A. (2001) 'The determinants of export performance: a firm-level study of Italian manufacturing', Review of World Economics, Vol. 137, No. 3, pp.450-472.

Teece, D.J. (1986) 'Profiting from technological Innovation: implications for integration, collaboration, licensing and public policy', Research Policy, Vol. 15, No. 3, pp.285-305.

Verwaal, E. and Donkers, B. (2001) 'Firm size and export intensity: solving an empirical puzzle', Journal of International Business Studies, Vol. 33, No. 3, pp.603-613.

Wagner, J. (2001) 'A note on the firm size - export relationship', Small Business Economics, Vol. 17, No. 4, pp.229-237.

Wakelin, K. (1998) 'Innovation and export behaviour at firm level', Research Policy, Vol. 26, pp.829-841.

Willmore, L. (1992) 'Transnationals and foreign trade: evidence from Brazil', The Journal of Development Studies, Vol. 28, No. 2, pp.314-335.

Woodward, J. (1970) Industrial Organization: Behaviour and Control, Oxford University Press, London.

Wooldridge, J.M. (2002) Econometric Analysis of Cross Section and Panel Data, 2nd ed., The MIT, London. 
Wooldridge, J.M. (2006) Introductory Econometrics: A Modern Approach, 4th ed., South-Western, Mason.

\section{Notes}

1 The World Bank Doing Business (2012) report ranks most of the TEs behind the developed economies in terms of their domestic business environment. The 'Doing Business Project', launched in 2002, provides objective measures of business regulations and their enforcement across 185 economies.

2 EBRD provides annual numerical indices for a range of reforms in transition economies. Scores assigned to reform levels range from 1 to $4+$. The lowest score represents no or little change from planned or centralised economy, whereas the highest scores represent advanced reforms and a situation similar to established market economies. The scores are based on the EBRD classification system, originally developed in the 1994 Transition Report and refined and amended in subsequent reports. '+' and '-' ratings are treated by adding 0.33 and subtracting 0.33 from the full values.

3 EBRD also identifies thresholds which identify the transition gap towards a fully reformed market economy. According to EBRD (2012), the transition gaps and their indices are set as follows: large gap, from 1 to 2+; Medium gap, from 2+ to $3+$; Small gap, from $3+$ to 4 and negligible gap $4+$. In order to test the sensitivity of the results to these thresholds, we have repeated this exercise with slightly different thresholds. The results, not reported here, are broadly similar to the estimates reported in Section 4 .

4 Business environment indicators are ranked on likert scale from 1 to 4 , as responses to the question: 'Can you tell me how problematic are these different factors for the operation and growth of your business'. Response ranking scales are as follows: 1 - no obstacle; 2 - minor obstacle; 3 - moderate obstacle; 4 - major obstacle. In BEEPS 2008, a fifth ranking scale, 5 - very severe obstacle was added.

5 For each variable, the dummy takes a value of 1 if one of the constituent indicators is considered a major obstacle, while other indicator/s are at least considered as moderate obstacles to firm's business operations. In POOLED3 dataset, contain all three survey rounds, infrastructure variable is constructed by combining only transport and telecommunication indicators; the weakness of rule of law is indicated only by anticompetitive practices of competitors; and macroeconomic instability was not included in the questionnaire.

6 There is insufficient evidence to reject the null hypothesis that the parameters of one dataset are equal to parameters of the other dataset.

7 In a separate specification, business environment obstacle are interacted with innovation indicators but the interaction terms appears insignificant in all estimations, which indicates that business obstacles have the same effect on innovators and non-innovators. Because the interaction term was not show significant, the results are not reported.

Comment [a1]: Author: Please confirm if this footnote should indeed be deleted from the list, even if it is cited in the text. Deleting this footnote indicates deleting the citation in the text and renumbering the succeeding footnotes.

Otherwise, kindly provide full reference for World Bank Doing Business (2012) or reconstruct this sentence. 


\section{Appendix}

Table A1 Correlation matrix of explanatory variables

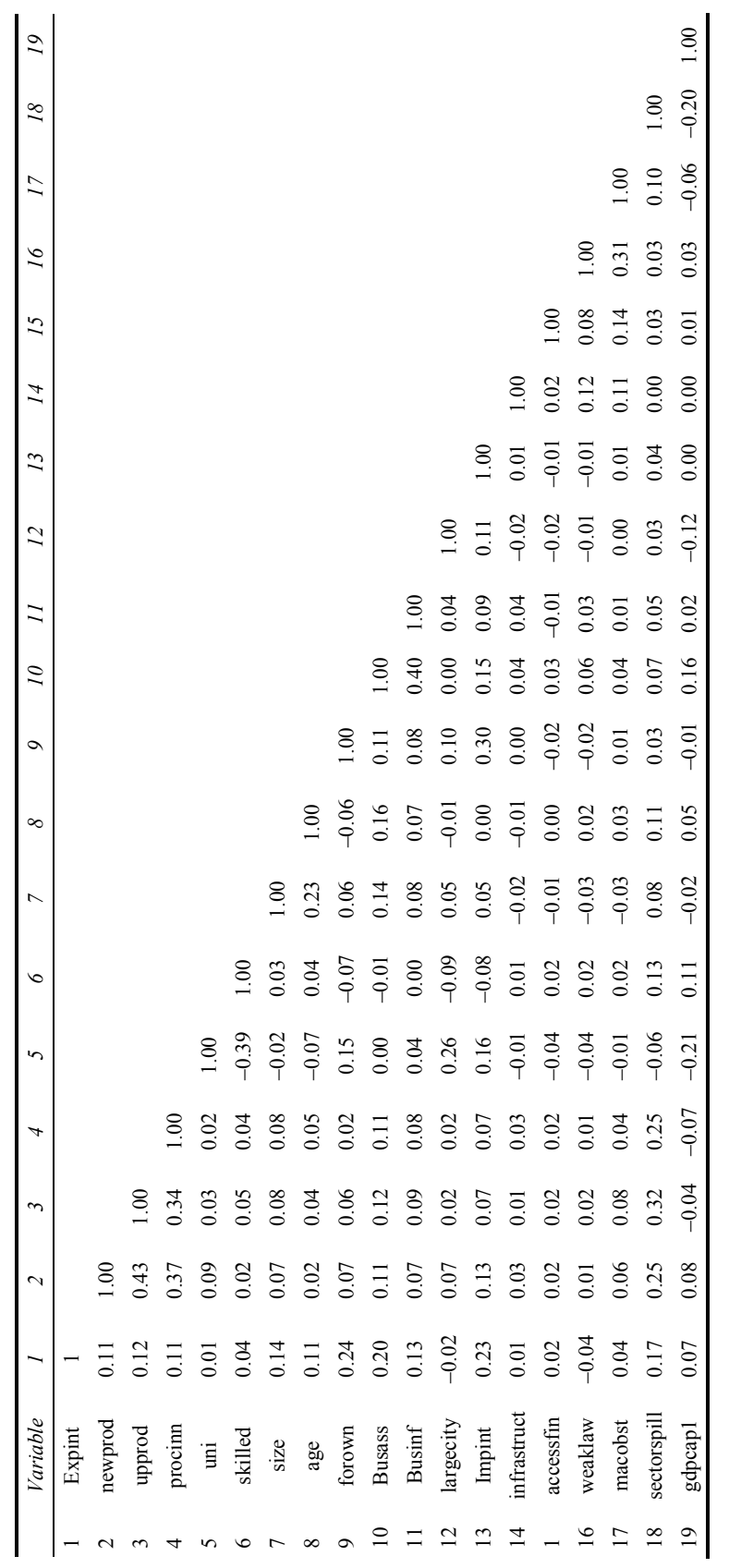


Table A2 Tobit unconditional marginal effects

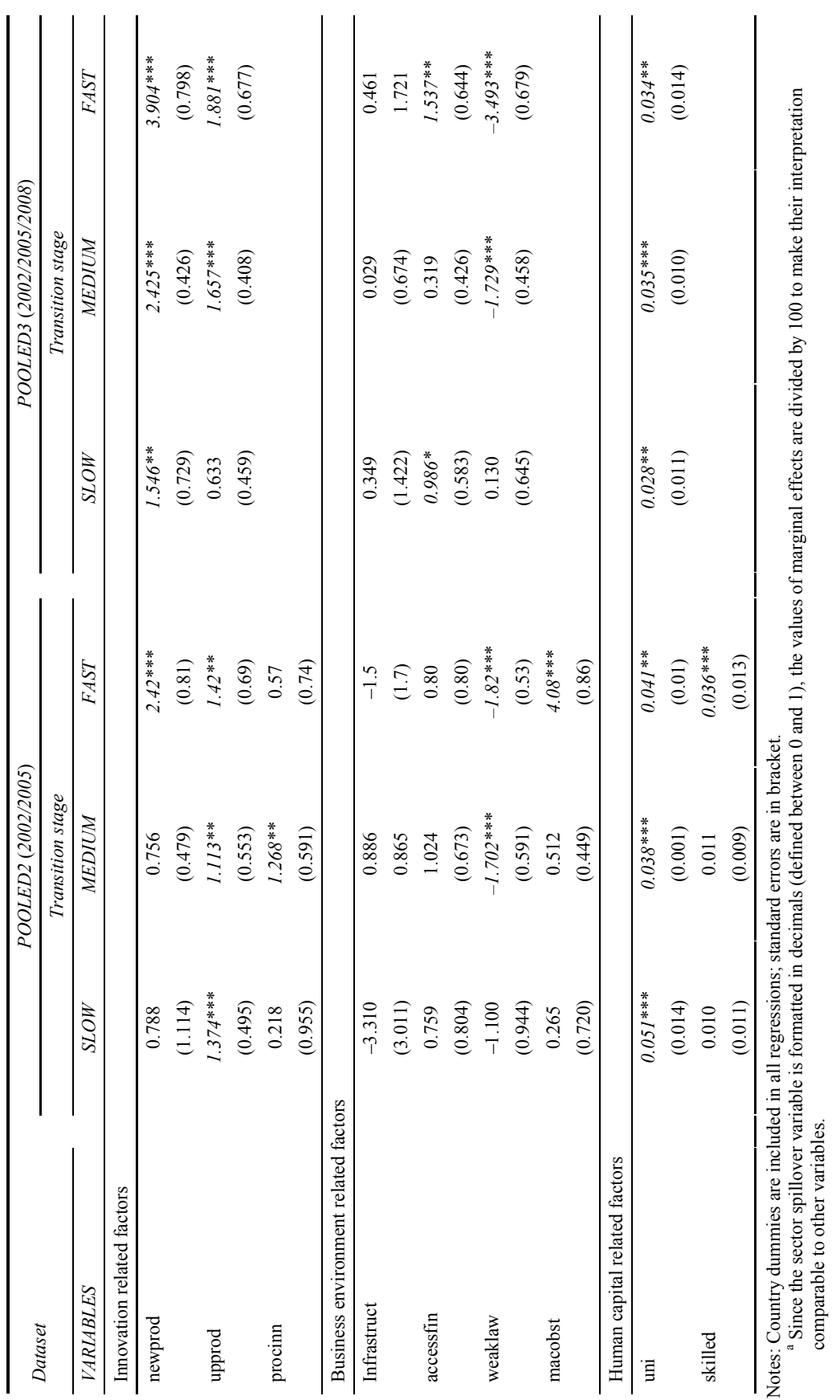




\section{$28 \quad$ F. Reçica et al.}

Table A2 Tobit unconditional marginal effects (continued)

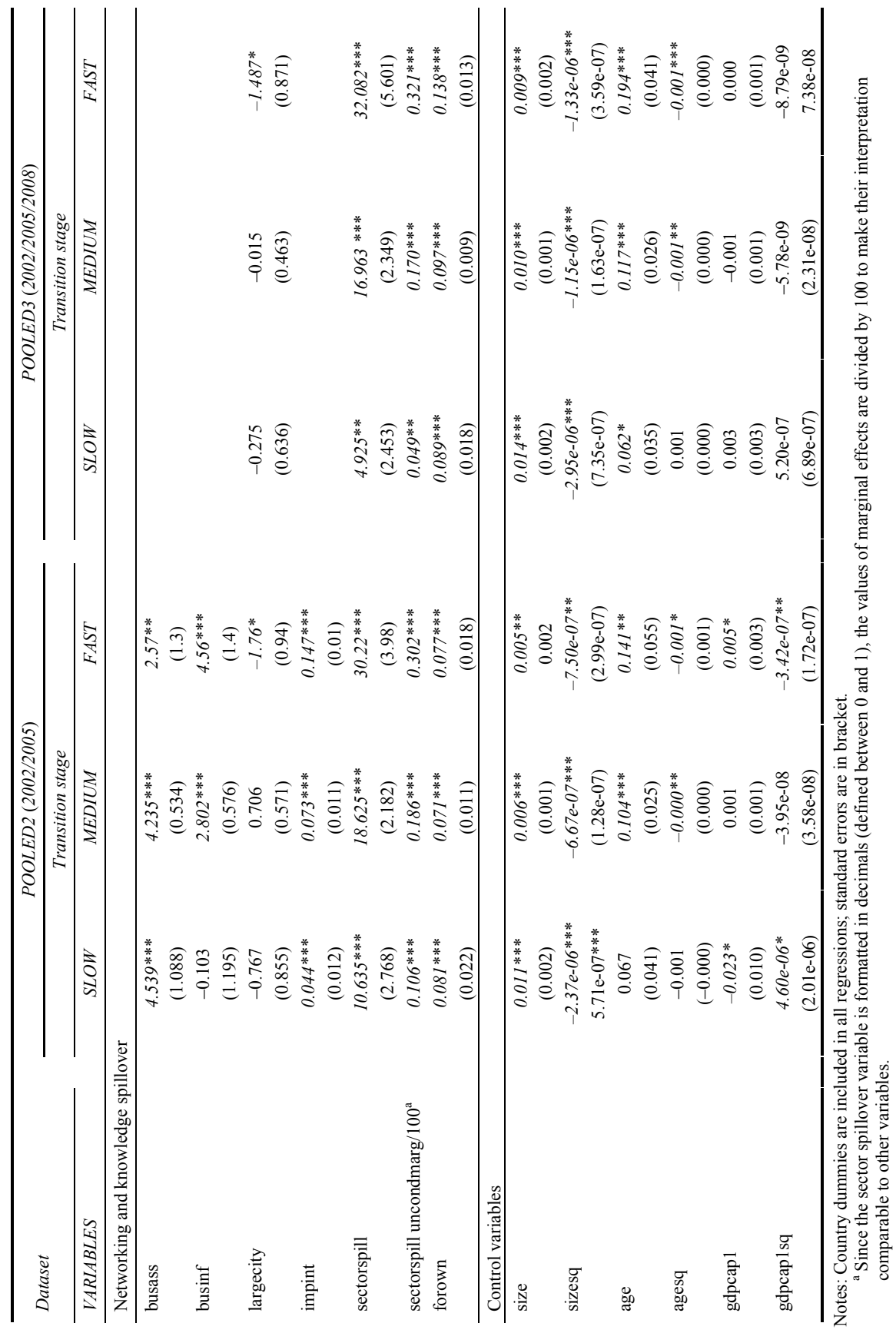


A1 Graphical presentation of average marginal effects of innovation variables (newprod, upprod) across stages of transition, using margins command

Figure A1 Pooled2 Tobit unconditional marginal effects of newprod across transition scores (1-4) (see online version for colours)

Variables that uniquely identify margins: trans

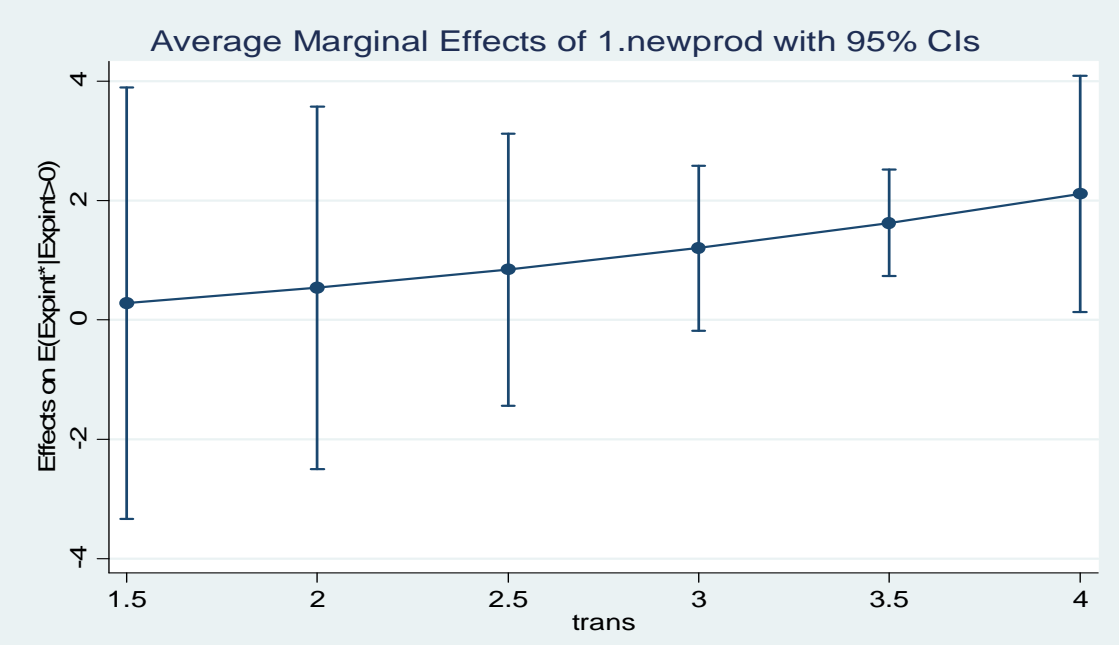

Figure A2 Pooled2 Tobit unconditional marginal effects of newprod across transition stages (see online version for colours)

Variables that uniquely identify margins: stages

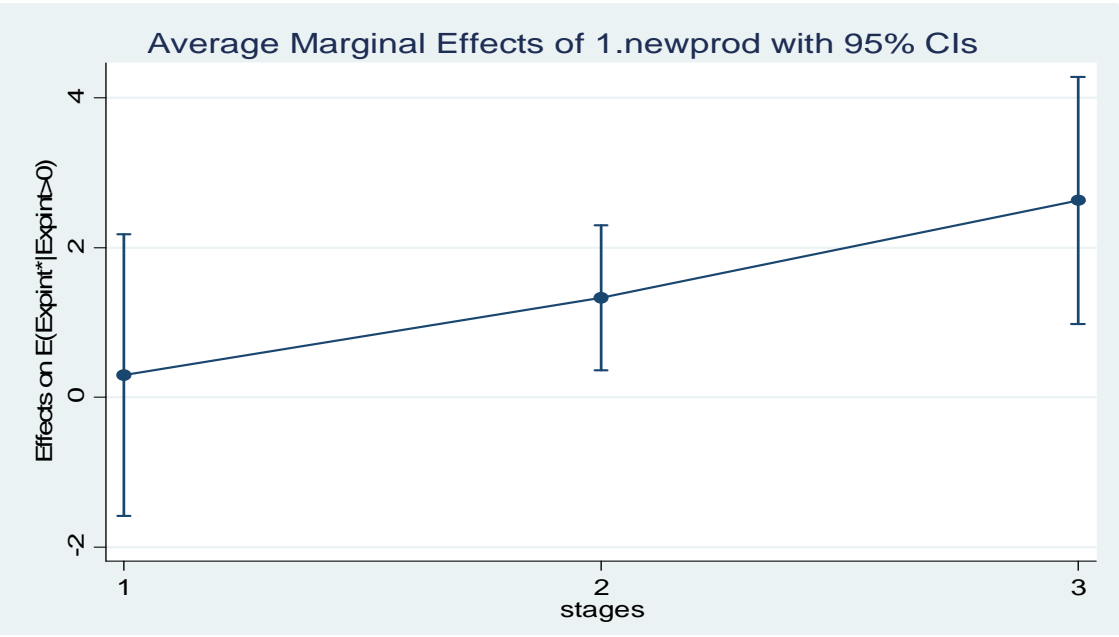


Figure A3 Pooled3 Tobit unconditional marginal effects of newprod across transition stages (see online version for colours)

Variables that uniquely identify margins: stages

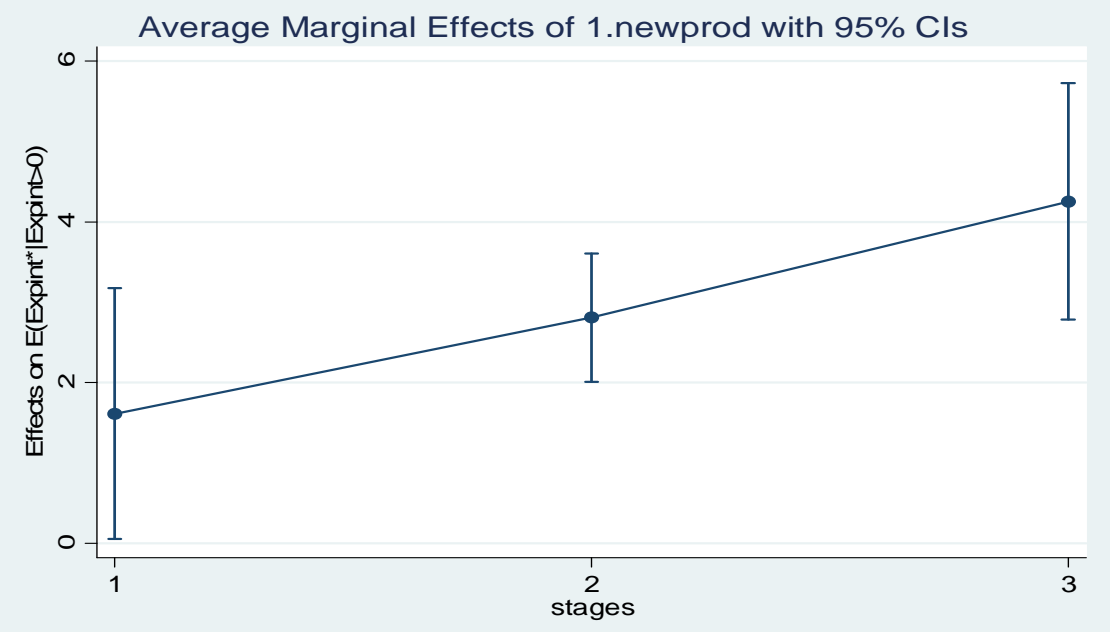

Figure A4 Pooled2 Tobit unconditional marginal effects of upprod across transition scores (1-4) (see online version for colours)

Variables that uniquely identify margins: trans

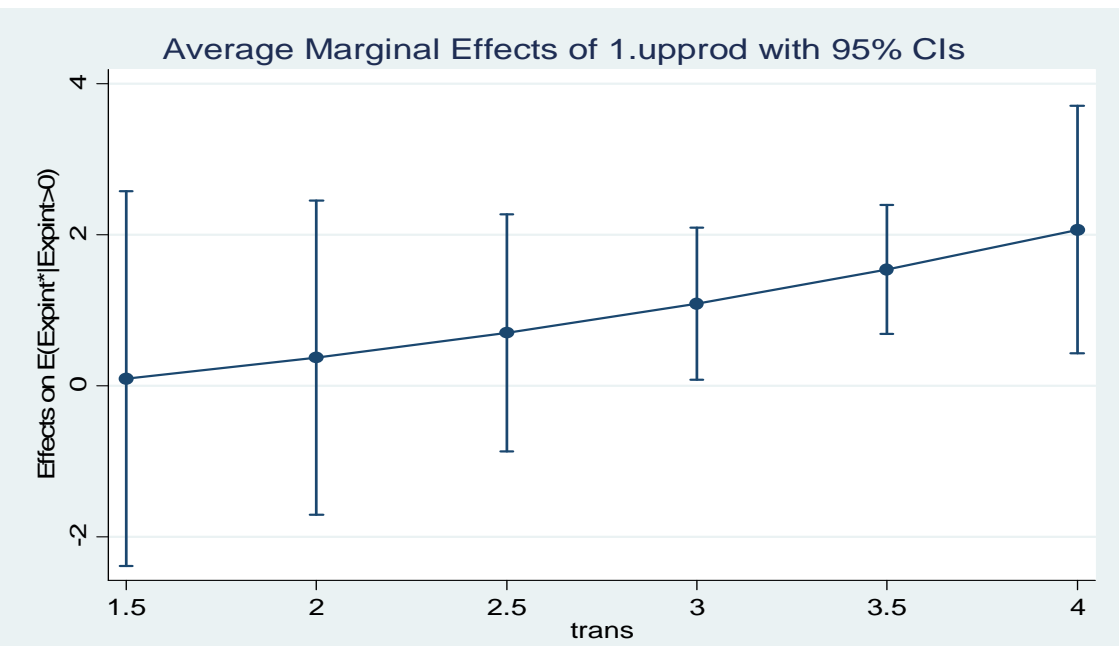


Figure A5 Pooled2 Tobit unconditional marginal effects of upprod across stages of transition (see online version for colours)

Variables that uniquely identify margins: stages

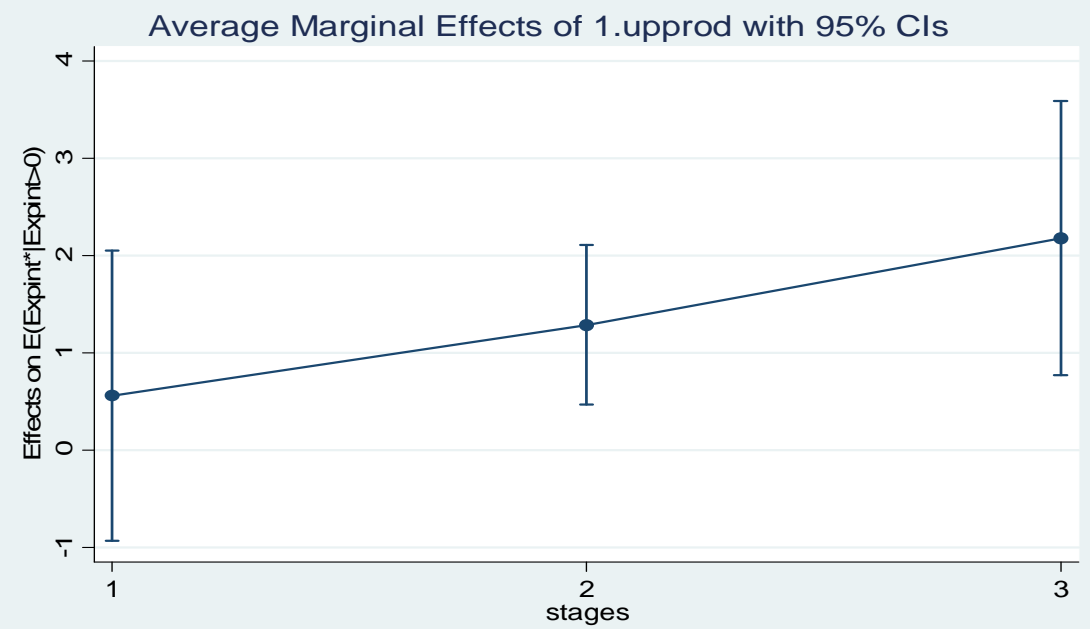

